\title{
Impact of Landuse Change on River Floodplain Using Public Domain Hydraulic Model
}

\author{
Abolghasem Akbari $^{1}$, Golamali Mozafari $^{2}$, Mohsen Fanodi $^{2}$ \& Maliheh Sadat Hemmesy ${ }^{3}$ \\ ${ }^{1}$ Faculty of Civil Engineering \& Earth Resources, University Malaysia Pahang, Kuantan, Malaysia \\ ${ }^{2}$ Department of Geography, Yazd University, Iran \\ ${ }^{3}$ Department of Geography, University of Lorestan, Khoramabad, Iran \\ Correspondence: Abolghasem Akbari, Faculty of Civil Engineering \& Earth Resources, University Malaysia \\ Pahang, Lebuhraya Tun Razak 26300 Gambang, Kuantan, Malaysia. E-mail: akbariinbox@yahoo.com
}

\author{
Received: May 5, 2014 Accepted: May 8, $2014 \quad$ Online Published: August 17, 2014 \\ doi:10.5539/mas.v8n5p80 URL: http://dx.doi.org/10.5539/mas.v8n5p80
}

\begin{abstract}
Floodplains are land areas adjacent to rivers and streams that are subjected to recurring inundation. Owing to their continually changing nature, floodplains and other flood-prone areas need to be examined in the light of how they might affect or be affected by landuse change. In this research, the effect of land use changes on floodplain is investigated. Major landuse change has occurred in Azaran watershed during the investigation period. Irrigated farmland has decreased by about $52 \%$. However, bare lands, dry farm lands, and rangeland have increased by $12.40 \%, 17.25 \%$ and $14.46 \%$, respectively. The extent of floodplain was determined based on the annual maximum instantaneous flood for different return periods using Hydrologic Engineering Centers River Analysis System (HEC-RAS) coupled with HEC-GeoRAS which is a tool for processing geospatial data in ArcGIS. Water surface profile data and velocity data exported from HEC-RAS simulations were processed by HEC-GeoRAS for floodplain mapping. It was found that the floodplain has increased due to land use change from 1956 to 2007. This study showed that floodplain areas in irrigated farmlands have increased by $151.99 \%$ and $68.63 \%$ for return period of 25 and 50 years, respectively.
\end{abstract}

Keywords: HEC-RAS, flood, floodplain, azaran

\section{Background of the Study}

Floodplains are land areas adjacent to rivers and streams that are subject to recurring inundation. Owing to their continually changing nature, floodplains and other flood-prone areas need to be examined in the light of how they might affect or be affected by landuse change. There are different factors that affect flood frequency including topographic characteristics, river morphology, environmental structures, and human activities. One of the most important effects of human activities on flood occurrence is landuse change and its inconformity with the land capabilities. In this regard, the importance of floodplain mapping, which has much utilization in floodplain management, is emphasized. In particular, hazard zonation in rural areas gives orientation to planners and settlements to stabilize their activities as well as economic development (Eftekhari, 2009). Recently major development has been made in river engineering using GIS tools and techniques. As a result, several commercial software packages are available that integrates GIS capabilities in spatial analysis with hydraulic modeling. The U.S. Army Corps of Engineers Hydrologic Engineering Center River Analysis System (HEC-RAS) is a public domain software that links with the ArcGIS software through HEC-GeoRAS (USACE, 2000). Numerous researches have been done to address effects of this phenomenon in different aspects and objectives. Neal et al. (2012) have comprehensively described the physical complexity needed to model floodplains. Several other researches have been reported substantial changes to catchment runoff and floodplain due to conversion of forest to pasture or the afforestation of grassed catchments. There are many reviews of these experiments in the literature, notably those of Zhang et al. (1999), Best et al. (2003), Siriwardena et al.(2006), Brath et al. (2006), Nirupama and Simonovic (2007), Wheatera and Evansb (2009), Sriwongsitanon and Taesombat (2011), Theiling and Burant (2013) and Wagner et al. (2013). Some of these researches including Wernera et al. (2005), Cook and Merwade (2009), Merwade et al. (2008) and more recently Alexakis et al. (2014) employed GIS and remote sensing techniques for the assessment of land use change impact on flood runoff. HEC-RAS is a well know and public domain software for flood modeling and is widely used by different 
researchers including Sanders (2007), Hagen et al.(2010) and Croke et al. (2014). The purpose of this study is to identify the areas located in floodplain based on two flood frequency interval. The second objective of this study is to assess the changes in floodplain boundaries due to landuse changes in 50 years between 1956 and 2007. This period was selected because the land use data and observed peak discharge are available for this period.

\section{Material and Methodology}

\subsection{Study Area}

The Azaran watershed is the unit of consideration for this research and is located northwest of Esfahan, Iran (see Fig.1). Geographically it extends from $33^{\circ} 39^{\prime} 57 \prime \prime \mathrm{N}$ to $33^{\circ} 44^{\prime} 45^{\prime \prime} \mathrm{N}$ and $50^{\circ} 59^{\prime} 46^{\prime \prime} \mathrm{E}$ to $51^{\circ} 15^{\prime} 07{ }^{\prime \prime} \mathrm{E}$ while its area encompasses 9601 (ha). Its elevation is range from $2030 \mathrm{~m}$ to $3400 \mathrm{~m}$ based on mean sea level. The predominant land use of Azaran is rangeland.

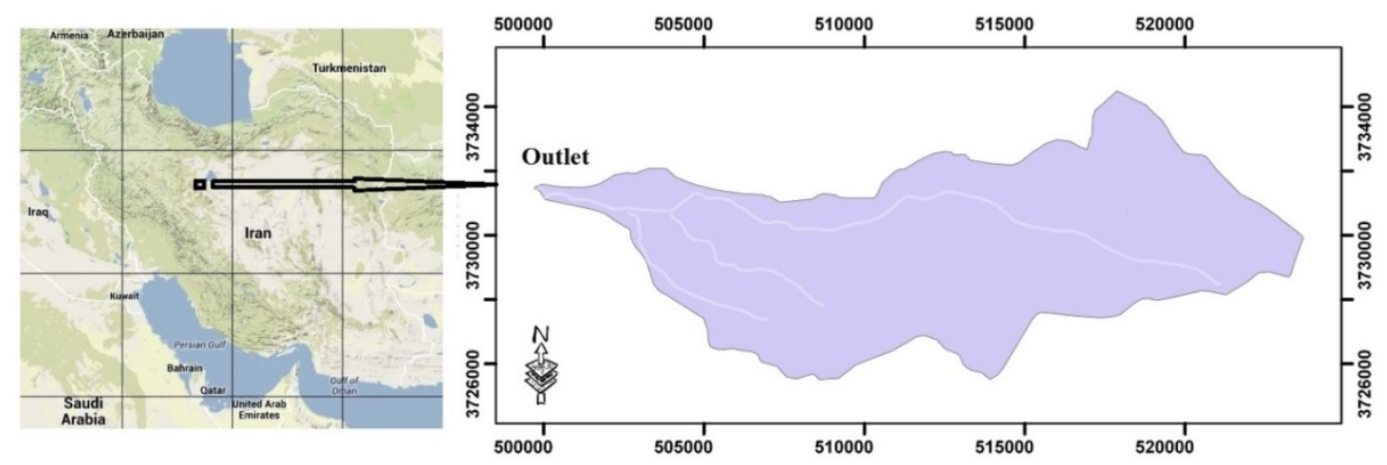

Figure 1. Layout of the study area

According to the Forest, Range and Watershed Organization of Esfahan, a landuse map of year 1956 had been generated using aerial photos at the scale of 1:55000 (Fig.2-a). A subsequent landuse map for 2007 was generated using Landsat satellite images (Fig.2-b). Roughness coefficients for the main channels were estimated according to the field survey of main rivers in the study area.
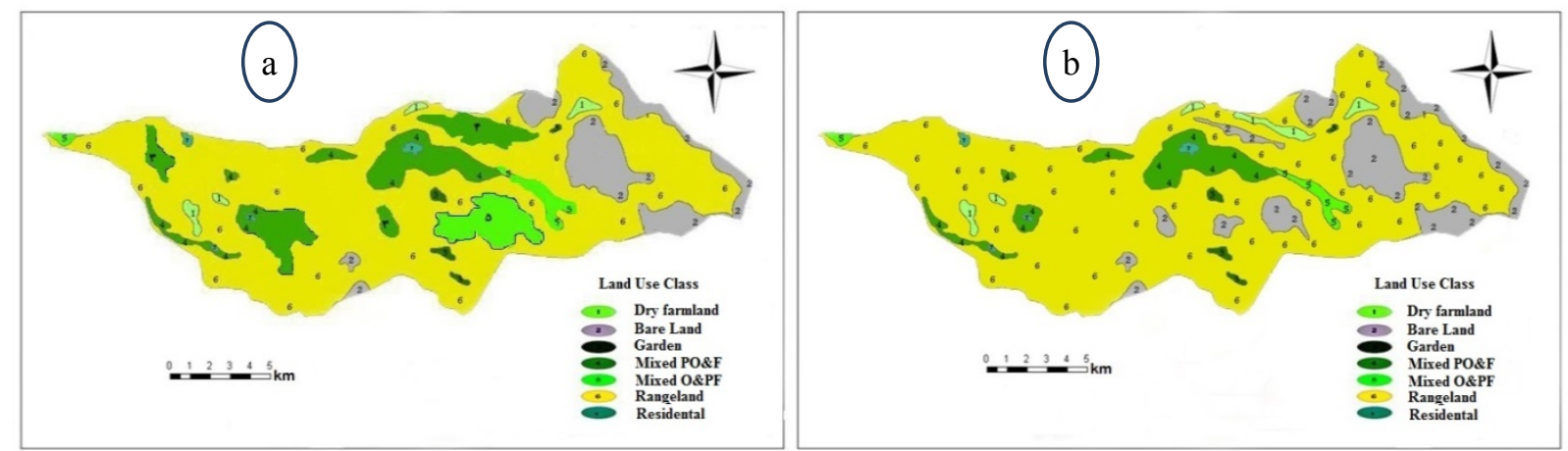

Figure 2. Representative landuse map of Azaran watershed for 1956 (a) and 2007 (b)

Table 1. Distribution landuse classes for Azaran watershed (1956 and 2007)

\begin{tabular}{llll}
\hline \multirow{2}{*}{ Landuse class } & $\mathbf{1 9 5 6}$ & $\mathbf{2 0 0 7}$ & Landuse changes \\
\cline { 2 - 4 } & Area(ha) & Area(ha) & $\%$ \\
\hline Dry farm & 289.79 & 339.79 & 17.25 \\
Bare lands & 1209.45 & 1359.45 & 12.40 \\
Gardens * & 315.97 & 146.11 & -53.76 \\
Mixed predominate Gardens and Farm * & 799.96 & 351.91 & -56.01 \\
Mixed predominate Farm and Gardens* & 937.91 & 489.85 & -47.77 \\
Fair to poor Rangelands & 5988.48 & 6854.45 & 14.46 \\
Residential area & 59.44 & 59.44 & 0.00 \\
\hline
\end{tabular}

*Irrigated Farmland. 
As is evident in table 1, there was no change in residential area. This is because there is no major population in this area. There are only a few small villages in which no development has been made due to long term drought and lack of water resources during the last 15 years.

\subsection{Maximum Instantaneous Flow Rate}

The maximum instantaneous flow rate for 34 years dataset were analyzed to determine the maximum flow rate for various return periods using the Stormwater Management and Design Aid (SMADA) software. The Log Pearson Type III distribution depicts a minimum standard deviation in comparison to other statistical measures. Instantaneous flow rates for different return periods are provided in table 2.

Table 2. Estimated maximum flow rate based on Log Pearson Type III distribution

\begin{tabular}{lll}
\hline Non- exceedance Probability & Return Period & $\mathrm{Q}\left(\mathrm{m}^{3} / \mathrm{s}\right)$ \\
\hline 0.5 & 2 & 17.71 \\
0.8 & 5 & 35.43 \\
0.9 & 10 & 57.09 \\
0.96 & 25 & 100.40 \\
0.98 & 50 & 147.23 \\
0.99 & 100 & 216.54 \\
0.995 & 200 & 358.28 \\
\hline
\end{tabular}

\subsection{Generation of Digital Terrain Model (DTM)}

The first step in the pre-processing stage is to create a Digital Elevation Model (DEM) of the river system in a Triangulated Irregular Network (TIN) format. The TIN must be constructed with special care in order to provide accurate analyses. Elevation data for each cross section is extracted from the TIN (Sredojevic and Simonovic, 2009). The TIN also serves to determine floodplain boundaries and calculation of inundation depths. The DEM is a representation of the topographical surface in terms of regularly spaced $\mathrm{x}, \mathrm{y}, \mathrm{z}$, coordinates. The DEM can be developed from a number of sources including ground survey, cartography, photogrammetry, surface sensing Lidar Data, Satellite data such as SRTM and ASTER-GDEM. The TIN-based model has a vector-based data structure, but it can be converted into grid cells. In the TIN model, each point has defined $\mathrm{x}, \mathrm{y}$, and $\mathrm{z}$ coordinates. The coordinate $\mathrm{z}$ represents the height. These points are connected by their edges to form a network of overlapping triangles (finite surfaces) that represent the terrain surface (Lo and Yeung, 2005). The basis of TIN-based DTM is that a large series of these finite surfaces, sharing common horizontal edges, can be linked together and used to interpolate the XYZ coordinate of any point, even though actual measurements have not been obtained at that point. In this research a Digital Elevation Model (DEM) was generated for the investigated river domain by using topographic map at a scale of 1:25000 collected from the National Cartographic Center of Iran, Esfahan branch.

\subsubsection{Creating River Center Line}

The river centerline layer is very important, because it represents the river network for HEC-RAS. Digitizing of the stream centerline starts with selecting the sketch tool from the Editor Toolbar, and digitization proceeds in the direction of river flow

\subsubsection{Creating River Banks}

The bank lines layer is used to define the river channel from overbank areas. This definition is important because Manning's n values are different for channel and for floodplain areas. Usually, the overbank areas have higher values of Manning's $\mathrm{n}$ due to vegetation or presence of residential areas.

\subsection{Manning Roughness Coefficient}

Manning roughness coefficients (n) represent the resistance to flood flows in channels and floodplains. The results of Manning's formula, an indirect computation of stream flow, have applications in floodplain management, flood insurance studies, and the design of bridges and highways across floodplains. Many researches have been done to determine Manning roughness coefficients. Among those, the research done by Gharib (2006), yan and zhong (2002) as well as Wong (2008) are notably comprehensive. To determine the Manning's n, field survey conducted and during the fieldwork representative pictures were taken from the left 
and right overbanks and main channels. Then, the Manning coefficient values were determined by field survey and justifying the taken photos with the above mentioned references.

\subsection{Pre-Processing HEC-RAS Results}

The use of the unsteady flow simulation features in the U.S. Army Corps of Engineers Hydrologic Engineering Center's HEC-RAS software program requires the use of geometry pre-processor to complete the hydraulic calculations. The correct selection of geometric parameters and review of the pre-processor output is an important factor in the successful execution of an unsteady flow simulation. The geometry pre-processor in HEC-RAS calculates a series of curves that describe the geometric and hydraulic properties of cross-sections, bridges, culverts, and weirs. The HEC-RAS modeler can modify several variables that affect the calculation of these curves. GeoRAS generates three additional data sets prior to using HEC-RAS. They are the 3D Centerline theme, the 3D Cross Section theme, and the RAS GIS Import File (Snead and Maidment, 2000). Upon successful implementation of the simulation, the HEC-RAS output is exported to HEC-Geo RAS for post-processing of the output. Post-processing facilitates the automated floodplain delineation based on the data contained in the RAS output file and the original terrain TIN. Using HEC-GeoRAS functionalities, the imported HEC-RAS results are processed with the TIN of the region to generate the flood water surface extents and the flood water depth files for return periods of 25 and 50 years. The water surface profile data is used to develop a water surface TIN, and the intersection of the water surface TIN with the terrain model TIN provides flood visualization. The results can be shown in 2-D or 3-D views.

\subsection{HEC-RAS Basic Concepts and Equations}

HEC-RAS is an integrated software system, designed for interactive use in a multi-tasking environment and used to perform one-dimensional water surface calculations (Sredojevic and Simonovic, 2009). HEC-RAS is comprised of a graphical user interface, separate hydraulic analysis components, data storage and management capabilities, and graphing as well as reporting facilities (USACE, 2010). The computation engine of HEC-RAS is based on the solution of the one-dimensional energy equation. Energy losses are evaluated by friction (Manning's formula), contraction, and expansion. In cases where the water surface profile varies rapidly, use of the momentum equation is necessary. These cases include: mixed flow regime calculations, bridge hydraulic calculations and evaluation of profiles at river confluence. Water surface is calculated from one cross section to the next by solving the energy equation written as:

$$
h_{e}=L \bar{S}_{f}+C\left|\frac{\alpha_{2} V_{2}^{2}}{2 g}-\frac{\alpha_{1} V_{1}^{2}}{2 g}\right|
$$

Where,

$V_{1}$ and $V_{2}=$ average velocities $\left(\mathrm{m}^{2} / \mathrm{s}\right)$

$g=$ gravitational acceleration

$\alpha_{1}$ and $\alpha_{2}=$ velocity weighting coefficients (dimensionless) and

$h_{e}=$ energy head loss (m).

$L=$ reach length between the adjacent cross sections

$\bar{S}_{f}=$ friction slope between the two sections and

$C$ = expansion or contraction loss coefficient (dimensionless).

The magnitude of $\alpha$ depends upon the channel characteristics. Typical values of $\alpha$ are shown in Table 3 .

Table 3. Magnitude of $\alpha$ after Debo and Reese (2002)

\begin{tabular}{lccc}
\hline \multirow{2}{*}{ Type of channel } & \multicolumn{3}{c}{ Value of $\boldsymbol{\alpha}$} \\
\cline { 2 - 4 } & Min. & Avg. & Max. \\
\hline Regular Channel & 1.10 & 1.15 & 1.20 \\
Natural Channel & 1.15 & 1.30 & 1.50 \\
Natural Channel-flooded overbanks & 1.50 & 1.75 & 2.00 \\
\hline
\end{tabular}




\section{Result and Discussion}

Surface water profile was derived based on flood frequency analysis as well as geometric and hydraulic specification of river cross sections. Validation of derived profile for return periods 50 -yr was made based on the identified watermarks for the flood occurred in June 27, 2007. Based on this watermark, the peak discharge is estimated to be $120 \mathrm{~m}^{3} / \mathrm{s}$, which is $16.6 \%$ is lower than the estimated flood by Pearson Type III distribution. Moreover, according to local inhabitant's reports, a similar flood has occurred in June 20, 1956. Therefore that flood can be considered with 50 -yr return period.

Based on this classification the floodplain was generated by intersecting the floodplain in 1956 and 2007. Delineation of floodplain due to landuse changes is vital for residential and agricultural landuse. The HEC-HMS was set for estimated flood flow for two return periods and water surface profile was determined. The Manning roughness was determined based on the field survey and available references. Floodplain maps were provided for 25-yr and 50-yr (see Fig.3). A comparison was made for this type of land use and presented in Table 4. It is because of the law made by local organizations specifically insurance companies that they insure only the farm and garden lands which are out of the buffer delineated by 50-yr flood in urban areas and 25 -yr in rural areas.
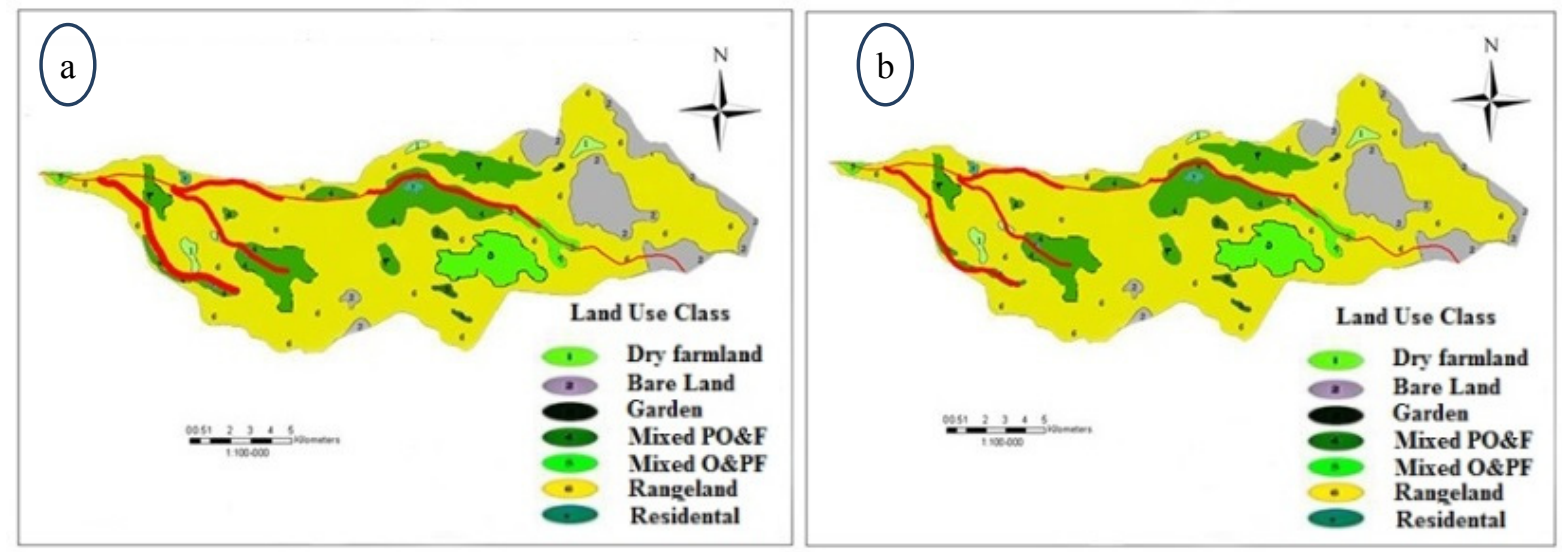

Figure 3. Floodplain area (Red color) for return period of 25-yr (a) and 50-yr (b) in Azaran watershed

Table 4. Irrigated farmlands inundated by flood with different return period

\begin{tabular}{lcc}
\hline \multicolumn{1}{c}{ Return period } & 25 & 50 \\
\hline Floodplain area of irrigated farmlands for land use 1956(ha) & 35.12 & 53.37 \\
Floodplain area of irrigated farmlands for land use 2007 (ha) & 88.50 & 90.00 \\
Difference (ha) & 53.38 & 36.63 \\
Percentage of extent & 151.99 & 68.63 \\
\hline
\end{tabular}

Some relationships were found between the floodplain and return period in Azaran watershed. Figure 4 illustrates the logarithmic relationship between maximum instantaneous flood and floodplain area with strong correlation coefficient of 0.94 for irrigated farmlands in Azaran watershed. This can be due to the fact that irrigate farmlands are in a floodplain with low slope $(<10 \%)$. Therefore, the floodplain area will rapidly increase with small increase in flood depth. It is evident that floodplain is exponentially decreased by increasing the return period. This trend enhances the importance of topography in floodplain in irrigated farmlands of Azaran watershed. 


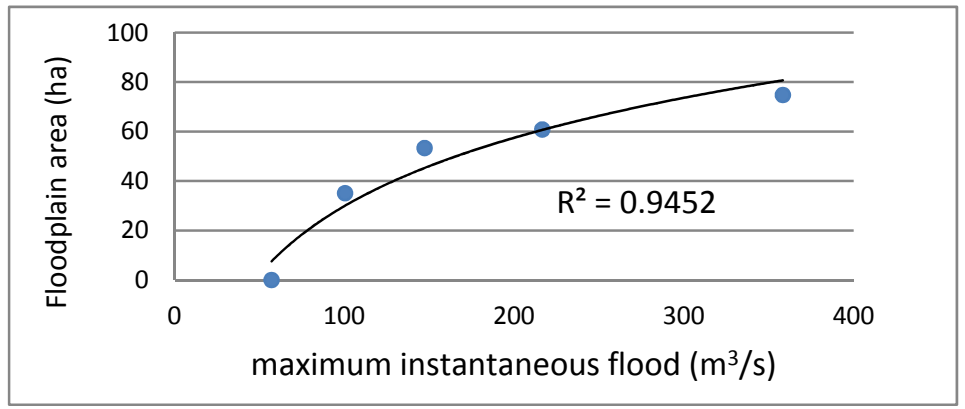

Figure 4. Relationship between maximum instantaneous flood and floodplain area in Azaran watershed

\section{Conclusion}

As there is no quantified data on the inundation depths for such a high magnitude flood hazard in the study region, the visualization and the quantification of the flood risks, as facilitated by this approach, can assist the decision makers to mitigate the catastrophic effects of floods. Combining the derived maximum floods by flood frequency analysis with surveyed watermarks gives a fair and reasonable confidence to the floodplain analysis and results. The Land use change analysis shows $52 \%$ decrease in irrigated farmlands. However, bare lands, dry farm lands, and rangeland have increased by $12.40 \%, 17.25 \%$ and $14.46 \%$ respectively. The analysis of water surface profiles shows that floodplain areas have increased in irrigated farmlands by $151.99 \%$ and $68.63 \%$ for return periods of $25-\mathrm{yr}$, and 50-yr respectively. Decreasing the floodplain by increasing the return period demonstrates the important role of topography in floodplain of Azaran's irrigated farmlands.

\section{References}

Alexakis, D. D., Grillakis, M. G., Koutroulis, A. G., Agapiou, A., Themistocleous, K., Tsanis, I. K., ... Hadjimitsis, D. G. (2014). GIS and remote sensing techniques for the assessment of land use change impact on flood hydrology: The case study of Yialias basin in Cyprus. Natural Hazards and Earth System Sciences, 14, 413-426. http://dx.doi.org/10.5194/nhess-14-413-2014

Brath, A., Montanari, A., \& Moretti, G. (2006). Assessing the effect on flood frequency of land use change via hydrological simulation (with uncertainty). Journal of Hydrology, 324, 141-153. http://dx.doi.org/10.1016/j.jhydrol.2005.10.001

Cook, A., \& Merwade, V. (2009). Effect of topographic data, geometric configuration and modeling approach on flood inundation mapping. Journal of Hydrology, 377, 131-142. http://dx.doi.org/10.1016/j.jhydrol.2009.08.015

Croke, J., Reinfelds, I., Thompson, C., \& Roper, E. (2014). Macrochannels and their significance for flood-risk minimisation: examples from southeast Queensland and New South Wales, Australia. Stochastic Environmental Research and Risk Assessment, 28, 99-112. http://dx.doi.org/10.1007/s00477-013-0722-1

Debo, T. N., \& Reese, A. (2002). Municipal Stormwater Management, Second Edition.

Eftekhari, A. (2009). The evaluation of flood risk zoning villages using HEC-GEORAS models in GIS: Case study: Gorganroud villages. Rural Development Journal, 1, 157-182.

Gharib, M. (2006). Risk Hazard Zonnation and Flood management assessment. Case Study: Gharehchai River area in Rummian Suburb. Journal of Faculty of Natural Resources, 60, 785-797.

Hagen, E., Shroder, J. F., \& Teuferta, J. F. (2010). Reverse engineered flood hazard mapping in Afghanistan: A parsimonious flood map model for developing countries. Quaternary International, 226, 82-91. http://dx.doi.org/10.1016/j.quaint.2009.11.021

Merwade, V., Cook, A., \& Coonrod, J. (2008). GIS techniques for creating river terrain models for hydrodynamic modeling and flood inundation mapping. Environmental Modelling \& Software, 23, 1300-1311. http://dx.doi.org/10.1016/j.envsoft.2008.03.005

Neal, J., Villanueva, I., Nigelwright, Willis, T., Fewtrell, T., \& Bates, P. (2012). How much physical complexity is needed to model flood inundation? HYDROLOGICAL PROCESSES, 26, 2264-2282. http://dx.doi.org/10.1002/hyp.8339

Nirupama, N., \& Simonovic, S. P. (2007). Increase of Flood Risk due to Urbanisation: A Canadian Example. 
Natural Hazards, 40, 25-41. http://dx.doi.org/10.1007/s11069-006-0003-0

Sanders, B. F. (2007). Evaluation of on-line DEMs for flood inundation modeling. Advances in Water Resources, 30, 1831-1843. http://dx.doi.org/10.1016/j.advwatres.2007.02.005

Siriwardena, L., Finlayson, B. L., \& Mcmahon, T. A. S. (2006). The impact of land use change on catchment hydrology in large catchments: The Comet River, Central Queensland, Australia. Journal of Hydrology, 326, 199-214. http://dx.doi.org/10.1016/j.jhydrol.2005.10.030

Snead, D., \& Maidment, D. R. (2000). Floodplain Visualization Using HEC-GeoRAS. Texas at Austin.: The University of Texas at Austin. Retrieved from http://www.crwr.utexas.edu/gis/gishydro01/class/exercises/georas.html 2013

Sredojevic, D., \& Simonovic, S. P. (2009). City of London: Vulnerability of Infrastructure to Climate Change Background.

Sriwongsitanon, N., \& Taesombat, W. (2011). Effects of land cover on runoff coefficient. Journal of Hydrology, 410, 226-238. http://dx.doi.org/10.1016/j.jhydrol.2011.09.021

Theiling, C. H., \& Burant, J. T. (2013). FLOOD INUNDATION MAPPING FOR INTEGRATED FLOODPLAIN MANAGEMENT: UPPER MISSISSIPPI RIVER SYSTEM. River Research and Applications, 29, 961-978.

USACE (2010). HEC-RAS, River Analysis System, Hydraulic User Manual, Version 4.1. In CENTER, U. H. E. (Ed.). USACE.

Wagner, P. D., Kumar, S., \& Schneider, K. (2013). An assessment of land use change impacts on the water resources of the Mula and Mutha Rivers catchment upstream of Pune, India. Hydrol. Earth Syst. Sci., 17, 2233-2246. http://dx.doi.org/10.5194/hess-17-2233-2013

Wernera, M. G. F., Hunter, N. M., \& Bates, P. D. (2005). Identifiability of distributed floodplain roughness values in flood extent estimation. Journal of Hydrology, 314, 139-157. http://dx.doi.org/10.1016/j.jhydrol.2005.03.012

Wheatera, H., \& Evansb, E. (2009). Land use, water management and future flood risk. Land Use Policy, 26, S251-S264. http://dx.doi.org/10.1016/j.landusepol.2009.08.019

Wong, T. S., \& F.Asce (2008). Optimum Rainfall Interval and Manning's Roughness Coefficient for Runoff Simulation. Journal of Hydrologic Engineering, 13, 1097-1102. http://dx.doi.org/10.1061/(ASCE)1084-0699(2008)13:11(1097)

Yan, W. L., \& Zhong, H. J. (2002). Composite Manning roughness coefficient of ice-covered flow. Journal of Wuhan University of Hydraulic and Electric Engineering.

\section{Copyrights}

Copyright for this article is retained by the author(s), with first publication rights granted to the journal.

This is an open-access article distributed under the terms and conditions of the Creative Commons Attribution license (http://creativecommons.org/licenses/by/3.0/). 